\title{
GCU
}

Glasgow Caledonian

University

University for the Common Good

\section{The entry mode strategy and performance of SMEs: evidence from Norway}

Nisar, Shaista; Boateng, Agyenim; Wu, Junjie

Published in:

Research in International Business and Finance

DOI:

10.1016/j.ribaf.2017.07.164

Publication date:

2018

Document Version

Author accepted manuscript

Link to publication in ResearchOnline

Citation for published version (Harvard):

Nisar, S, Boateng, A \& Wu, J 2018, 'The entry mode strategy and performance of SMEs: evidence from Norway', Research in International Business and Finance, vol. 45, pp. 323-333. https://doi.org/10.1016/j.ribaf.2017.07.164

\section{General rights}

Copyright and moral rights for the publications made accessible in the public portal are retained by the authors and/or other copyright owners and it is a condition of accessing publications that users recognise and abide by the legal requirements associated with these rights.

Take down policy

If you believe that this document breaches copyright please view our takedown policy at https://edshare.gcu.ac.uk/id/eprint/5179 for details of how to contact us. 
The Entry Mode Strategy and Performance of SMEs: Evidence from

\title{
Norway
}

\author{
By \\ Shaista Nisar ${ }^{\mathrm{a}}$, Agyenim Boateng ${ }^{\mathrm{b}}$, Junjie $\mathrm{Wu}^{\mathrm{c}}$ \\ ${ }^{\mathrm{a}}$ University of Tampa, Florida, USA \\ ${ }^{\mathrm{b}}$ Law, Economics, Accounting \& Risk, Glasgow Caledonian University, UK \\ ${ }^{\mathrm{c}}$ Faculty of Business and Law, Leedsbeckett University, UK \\ *Correspondence to: \\ Professor Agyenim Boateng, \\ Law, Economics, Accounting \& Risk, Glasgow Caledonian University \\ 70 Cowcaddens Road, Glasgow, UK G4 0BA \\ Phone: + 44 (0) 1412731116 \\ agyenim.boateng@gcu.ac.uk
}




\title{
The Entry Mode Strategy and Performance of SMEs: Evidence from Norway
}

\begin{abstract}
:
The relationship between foreign entry mode choice and the performance of small-medium sized enterprises (SMEs) has been an overarching theme of research of the past decade. However, the research in this area has been hampered by the difficulty of defining and measuring performance. In this study, we used a multi-item measure of performance, which takes into account the relative importance of each measure and the perceived level of satisfaction, to analyse 146 SMEs in Norway. Our regression analysis shows that firm characteristics: size and sector of operation, significantly influence performance. However, prior international experience did not significantly influence performance. In terms of entry mode via international joint venture, trust and congruity of goals between partners have a positive and significant influence on performance.
\end{abstract}

\section{Keywords: Entry Strategy, SMEs, Performance, Norway}

\section{Introduction}

The entry mode choice is one of the most important decisions in a small firm's internationalisation strategy because it determines the amount of resources to be committed, the level of control and market implementation strategy in the host country. These factors have major implications for performance (Caves and Mehra, 1986; Brouthers, 2002; Brouthers and Nakos, 2004; Tsai and Tung, 2014). However, despite the advances in entry mode theory, there remains a gap in our understanding of the performance implications of entry mode by SMEs (Brouthers, Brouthers and 
Werner, 2003; Choo and Mazzaral, 2001; Schwens, Eiche and Kabst, 2011; Stoian, Rialp, and Dimitratos, 2016). Small firm characteristics, such as limited financial resources, ownership structure, managerial styles and managerial resources, suggest that the international strategies and structures of SMEs differ from large multinationals. However, past empirical efforts have concentrated on large multinational firms (see, Coviello and McAuley, 1999; Carrier, 1994). This raises the question: do SMEs characteristics lead to an improved performance? While past empirical efforts have attempted to address this important question, albeit in a limited way, it is pertinent to note that studies have produced mixed and inconclusive results. For example, Brouthers and Nakos, 2004 and Lu and Beamish, 2001 found a positive relationship between entry mode and performance, others found no effect (Morck and Yeung, 1991; Hoskinsson and Hitt, 1990, Geringer et.al., 1989); and still Collins, (1990); Kumar, (1984); Shaked, (1986) found negative effects.

A number of researchers attribute the inconsistent results to the difficulty of measuring the key dependent variable (i.e., performance). Researchers have highlighted the lack of uniformity across different studies and the employment of one or two performance measures that may not fully capture the performance of the SMEs, especially if the objective of the firm is broad (see Geringer and Hebert, 1989; Pangarkar, 2008). In this paper, we attempt to address the issue of performance measurement by adopting a broad multi-item measures, which encompass product market outcomes, accounting and market-based measures, human resources measures, customer satisfaction and other objectives of the respondent firms. An intriguing 
aspect of our investigation is that we take into account both the relative importance and the level of satisfaction when measuring the performance of each respondent firm. We believe that such a measure represents the true economic health of the firms in the study sample. The overall purpose of this paper is to examine the measures of performance and consider firm-specific and selected contextual factors that may influence the performance of three equity modes of entry in Norway by SMEs: international joint ventures (IJVs), cross border mergers and acquisitions (CBM\&As) and foreign wholly-owned greenfield start-ups (FWOGS) by SMEs.

The choice of Norway is significant because Norway is a small developed country, very open, and highly dependent on natural resources, which makes this study different from prior studies based on the U.S., UK and other developed countries. The Norwegian market attracts most of its investment opportunities to few target sectors including the high-tech, natural resources and service sectors (Boateng et al, 2015). Moreover, as SMEs tend to have relatively limited resources and the foreign direct investment (FDI) inflows in Norway are concentrated on extractive and high-technology industries, which are capital intensive in nature, it would be interesting to assess the performance implications of the choice of entry mode.

The remainder of the paper is organised into five sections. The following section reviews the relevant literature and presents the hypothesis of the study. Section three describes the methodology and sample characteristics. Section four presents the 
statistical analysis and discussion of results. Section five provides the managerial implications and conclusion.

\section{2 . Relevant Literature and Hypotheses}

\subsection{Entry Mode Choice and Performance}

Cross-border expansion is one of the most important ways for firms to grow. Barringer and Greening (1998) argue that geographic expansion is even more important for SMEs' growth strategy, especially given that small business scope tends to be geographically restricted. By entering into new markets, SMEs can enjoy a number of benefits including broadening their customer base, capitalising on market imperfections to achieve higher returns and leveraging core competencies across a broader range of markets (Zahra, Ireland and Hitt, 2000; Lu and Beamish, 2001). However, Lu and Beamish (2001) note that while geographic expansion presents important opportunities for SMEs growth and value creation, there are a number of challenges and difficulties that may erode the purported benefits of internationalisation. Prominent among the factors that can a pose challenge for SMEs expanding abroad are liabilities of foreignness (Hymer, 1976) and behavioural and environmental uncertainties (Brouthers and Nakos, 2004).

Behavioural uncertainties arise from the inability of a company to predict the behaviour of individuals in a foreign country, which leads to opportunistic behaviour such as cheating, distorting information, and other types of dishonest behaviour (Williamson, 1985; Anderson and Gatignon, 1986). Environmental uncertainty 
denotes the inability of an organisation to predict future events (Milliken, 1987), and it often results from the volatility of environmental conditions in the host country (Hill and Kim, 1988). According to Williamson (1985, Hennart (1989) and Williamson and Ouchi (1981), the above uncertainties create two main costs: market transaction costs and control costs. In the context of Norway, it is argued that behavioural and environmental uncertainties may be especially important, given that most investments occur in high-technology and natural resources sectors, and these sectors require the use of proprietary technology, which have high transaction and control costs (Nisar et al, 2012). Oviatt and McDougall (1995) suggest that, because of these uncertainties, it is required to differentiate between how we do business in international markets and domestic markets. Given that SMEs tend to rely on the managerial abilities of one or two entrepreneurs and have less well-developed management teams (Oviatt and McDougall, 1997; Okręglicka et al. 2015), it is argued that SMEs may not have the ability to establish a competent managerial control structure in another country. Even if, the SMEs are willing to establish and increase control in a foreign country, establishing a foreign presence involves committing additional resources, which may increase SMEs' exposure to external environmental risks (Erramilli and Rao, 1985; Klein et al., 1990). The problems of expanding abroad become even more acute given the limited resources and the small nature of most SMEs. This tends to magnify the negative implications of SMEs expansion activity. One way to reduce the difficulties associated with SMEs' geographical expansion is the choice of entry mode. For example, it is argued that in countries characterised by 
high environmental uncertainty, SMEs may be better off selecting a relatively low equity investment mode, such as IJV, to retain their flexibility, share costs and risks and increase their chances of better performance.

Regarding behavioural uncertainty, internalisation theorists argue that the high equity entry mode of FDI, such as FWOGS, enable firms to minimise transaction-related risks through internalising markets for proprietary asset exchanges (Hennart, 1982; Rugman, 1982; Laufs and Schwens, 2014). Besides the benefits gained from the internalisation of proprietary asset exchanges across international borders, outward direct investment by SMEs in diversified locations enable them to obtain various location-based advantages (Kogut, 1985), such as access to critical resources (Deeds and Hill, 1998) to develop new knowledge and capabilities that enhance their international competitiveness and, consequently, their performance. While the equity mode of FDI entry is likely to bring in these potential benefits, it is pertinent to point out that equity modes are not risk-free and still have problems. For example, IJVs have problems such as goal conflicts, distrust and disputes over control, which may lead to poor performance (Kogut, 1989; Hamel, 1991; Deeds and Hill, 1998). IJVs as an entry mode are no guarantee to SMEs' successful entry into international markets (Weaver and Dickson, 1998). In summary, the use of various equity modes of entry might bring positive economic benefits, but the modes have the potential to escalate the control problems and coordination costs and reduce or even reverse the long-term benefit of internationalisation, which could lead to poor SMEs performance. However, relatively little attention has been paid to the impact of firm characteristics and other 
context factors influencing SMEs' performance. To Brouthers and Nakos (2004) and Laufs and Schwens (2014), the impact of entry mode choice on performance remains less clear and this study attempts to fill that void.

\section{Measures of Performance}

The debate over organisational performance and measurement has been a controversial topic for theorists and management practitioners in all types of organisations (Andersson et al., 2001; Benito et al., 2003; Venkatraman and Ramanujam, 1986). While there have been many attempts to define and measure the organisational performance, consensus still eludes researchers on the appropriate definition and measurement of this concept (Lewin and Minton, 1986; Boateng and Glaister, 2002; Elnihewi, Fadzil, Mohamed, 2014). A major problem here is the choice of an appropriate yardstick(s) for assessing performance (Andersson, et al., 2001). This recognition is supported by Ismail et al. (2010) who stated that it is important to capture not only the financial aspect of business performance but also the non-financial elements. Thus, an effective multifaceted measurement system should be applied. Moreover, many researchers suggest that increased financial performance may not occur for a number of years after initial foreign market entry but that other measures of performance may help to determine the effectiveness of the investment (Anderson, 1990; Geringer and Hebert; 1991). Consistent with the arguments above, this study uses financial and non-financial performance measures to assess the performance of IJVs, CBM\&As and FWOGS in Norway. 


\section{Development of Hypotheses}

\subsection{Firm size and performance}

The issue of size and performance relationship has been raised by a number of authors, but the results are mixed (see, Ketokivi and Schroeder, 2004; Bhattacharyya and Saxena, 2009; Ainuddin et al., 2007; and Ismail et al., 2010; Benito-Osorio et al. 2016). Researchers have suggested that small firms suffer from size disadvantages that tend to inhibit their ability to compete internationally and consequently affect their performance (Levitt, 1985; Becker and Porter, 1988; ). For example, it is argued that SMEs are limited in their entry options due to a lack of human resources and capital and limited access to sophisticated information (Kaufman, 1995; Papadopolous, 1987; Benito-Osorio et al. 2016). Against this backdrop, Zacharakis (1997), and Erramilli and D'Souza (1993) suggest that limited resources may lead them to very different strategic choices compared to large firms. This suggests that SMEs may enter foreign markets via cooperative arrangements to overcome their lack of resources. However, a survey by DFAT (1995) indicates that sole ventures appear to be the most popular entry mode choice by SMEs. In terms of size and performance, the results have so far been mixed. For example, Chen and Findlay (2003) stated that a larger size may lead to economies of scale, market power and better performance. However, studies by Boyd and Graham (1991) and Berger (1995) concluded that larger size does not always mean profitability and, consequently, efficiency. 
On the other hand, Ingham et al. (1992) suggested that smaller acquisitions are more beneficial because they are easier to integrate, leading to managerial, operational and financial synergies. Others suggest that the size of the firm is more crucial for sole ventures where firms are relying entirely on their own capabilities. In the light of the above, we hypothesise that:

H1: The size of the firm will be positively related to the performance of IJV, CBM\&As and FWOGS.

\subsection{Sector of operation and performance}

Traditionally, one of the main motives for FDI in Norway has been to seek natural resources. Entry into manufacturing sector, which includes natural resources in this study, is important to Norway, and the government actively encourages MNEs through incentives to engage with state and other local organisations to bring in new technology and skills to develop the resource-intensive sectors (Nisar et al. 2012). Stretching this argument to the various entry strategies of FDI, an entry through IJV or CBM\&A may facilitate the achievement of the above objectives. As a result, the transaction costs in these sectors are more likely to be lower compared to other sectors. Despite this, no study has explicitly examined the relationship between the sectors, performance and entry mode choice in Norway. In the light of the above, we hypothesised that 
H2: The sector of operation relating to manufacturing sector will be positively related to the performance of IJVs, CBM\&As and FWOGS.

\subsection{Ownership type and performance}

The ownership type of a company may influence how the company is financed and managed and, consequently, its performance (Boateng and Glaister, 2002). Historically, the desire for national control of natural resources through IJVs has been a driving force behind state ownership of investments in Norway (NHO, 2003). The establishment of Statoil AS, the state oil company, in 1972 is a prominent example of the dominance of government ownership in the Norwegian economy (OECD, 2003). Although, in recent years, we have seen an increasing shift towards the private sector (SSB, 2014), state ownership still dominates in Norway. However, we have seen the exposure of state monopolies to competitive market forces. Privatisation, where it has occurred, has been carried out on a case-by-case basis, according to the pragmatic circumstances of the companies concerned and the external environment. Norway's entry into the European Economic Area Agreement (EEA) in 1994 brought several regulatory changes and increased competition in Norwegian markets (Ellingsen, 2008). What is more apparent is the increasing exposure of state-owned monopolies to competitive forces to improve performance (OECD, 2010). However, no study in Norwegian context has tested the impact of ownership type on performance. This discussion leads to the following hypothesis: 
H3: Ownership type of the company will be positively related to the overall performance of IJVs, and negatively related to the overall performance of CBM\&As and FWOGS.

\subsection{Previous international experience and performance}

The literature suggests that there is a connection between the previous international experience and the development of firm-specific processes and systems that can be exploited internationally (Brouthers and Nakos, 2004). This view is consistent with the internationalisation theory, which suggests that firms develop skills controlling international operations through experience (e.g., Johanson and Vahlne, 1977, 1990). For example, Evans et al. (2008) argue that organisations with limited international experience can overestimate the similarities between their home market and the foreign market "on the basis of superficial observations that are often made from a distance"' (Evans et al., 2008: 38). With international experience, the "liability of foreignness" is reduced, and the firm stands a better chance of survival as a foreign unit (Delios and Beamish, 2001; Li and Guisinger, 1991; McCloughan and Stone, 1998; Pan and Chi, 1999; Shaver et al., 1997; Woodcook et al., 1994) and achieving success in the foreign market at the post-entry stage (Maekelburger, Schwens, and Kabst, 2012). In a survey on economic performance of Scandinavian firms with subsidiaries in China, Carlsson et al. (2005) reported that experience with foreign countries outside of Mainland China had a positive impact on the subsidiaries' performance. Moreover, whereas Beamish and Lupton (2009) and Dikova (2009) 
report positive effects of previous experience on the performance of shared ownership, Hayward (2002) states that while people undertaking M\&A have a great opportunity to learn from their experiences, they seldom do. He found that previous experience is not enough to generate superior performance. On balance, however, more evidence supports the fact that experience is perceived to be a contributing factor towards enhancing firm performance and that firms with previous international experience are likely to perform better than firms without it. Consequently, we put forward the following hypothesis:

H4: Previous international experience will be positively related to the overall performance of IJVs, CBM\&As and FWOGS

\subsection{Trust and convergence of strategic goals between IJV Partners}

Many scholars have recognised that trust between partners is a key factor in improving the performance of IJVs (see, for example: Boersma et al. 2003; Gabbarro, 1978; Madhok, 1995; Parkhe, 1993a; Ring and Van De Ven, 1994; Uzzi, 1997; Larimo, Nguyen, and Ali, 2016). The transaction cost theory argues that trust is a transaction-cost-reducing mechanism that lowers the risk of entering into an agreement because it "economises on the specification and monitoring of contracts and material incentives for co-operation" (Noteboom, 1996). IJV contracts involve both ex ante and ex post transaction costs. Ex ante costs include drafting, negotiating and safeguarding an agreement. Ex post costs are more complex because they include 
elements of uncertainty, such as the JV partner's decision to default the agreement. Boersma et al. (2003) and Liu et al. (2010) state that both ex ante and ex post elements are reduced by trust and the subjective probability of ex post transaction failure declines when the parties trust one another. Despite the importance of trust between partners in improving the profitability of joint ventures, studies by Berger et al. (1995) and Nootebom et al. (1997) suggest a negative effect of trust on perceived dependence on the joint venture partner.

Ainuddin et al. (2007) argue that most joint ventures are formed to generate synergies and profits, and consequently performance. Beamish and Delios (1997) and Larimo, Nguyen and Ali (2016) argue that poor performance of an IJV may occur when the partners disagree on the objectives of the organisation. Child and Yan (2003) stated that the poor performance of IJV is also caused by the differences in goals between the parents. In examining the reasons for conflict in 40 Russian IJVs, Fey and Beamish (2000) reported that the greater the similarity between IJV parent firms' organisational climates, the more likely the joint venture would avoid conflicts. Beamish and Lupton (2009) stress the importance of establishing congruity in performance objectives at the establishment stage of the IJV. They further argue that consensus between the partners about the strategic goals of the IJV results in higher performance; when the congruency is lacking, poor performance is observed. This leads to the following hypotheses for IJVs as entry mode choice: 
H5 a: Trust between partners will be positively related to the overall performance of $I J V$.

H5 b: Congruence of strategic goals between partners will be positively related to the overall performance of IJV.

\section{Research Methodology and Sample Characteristics}

\subsection{Data Collection Method}

The data were gathered via a cross-sectional survey using a questionnaire on a sample of IJVs, CBM\&As and FWOGS in Norway. The development of the questionnaire was guided by the literature review, consultation with 5 academics with research interests in the area, and a pilot test. The research population of interest was obtained from a secondary source - the Dun \& Bradstreet database of companies in Norway in 2009. Only firms with the obligation to submit annual accounts were included in the sample because such companies keep proper records, which helps to facilitate proper data collection. According to the Norwegian sector-classification codes for companies, these firms were further grouped into two main sectoral distributions as follows: i) Manufacturing: high-tech companies, mining and quarrying, building and construction and ii) Services: financial intermediation and insurance, real estate and commercial services. These two sectors receive the bulk of FDI in Norway and provide the necessary data to carry out research in this area.

The statistical central bureau of Norway (2011) reported that manufacturing, mining and quarrying, building and construction amounted to $49 \%$ of total inward FDI in 
Norway in 2009 and that financial intermediation and insurance, real estate and commercial services amounted to $25 \%$. Bearing in mind the importance of these industries in the Norwegian inward FDI, this study focuses on the "manufacturing" and "service" sectors. Our definition of the entry modes included in our sample is as follows. First, an IJV is where two or more distinct organisations each participate in the decision-making activities of a jointly owned entity where at least one parent is headquartered outside the venture's country of operation (Geringer, 1990). This study comprises only equity JVs, which are a subset of inter-firm collaborative activity. A venture is an IJV where foreign equity ownership ranges from 11 to $90 \%$. Second, an FWOGS is a venture with foreign equity shareholding of over $90 \%$ and that was started from the scratch by the foreign investor. These definitions are consistent with the definitions used by US Department of Commerce. Third, a CBM\&A is described as when one firm acquires over $50 \%$ of the equity of another firm in a foreign country (UNCTAD, 2000). Moreover, companies for which full addresses were not available in the Bronnoysund Registrene (the register authority and the central source of information in Norway) are also excluded from the sample. The criteria produced a total of 353 companies: 90 IJVs, 109 CBM\&As and 154 FWOSs.

The questionnaire was distributed via e-mail, postal mail and personal delivery to 353 small medium-sized multinational firms in Norway in the last week of August 2009. The questionnaire was accompanied by a cover letter explaining the purpose of the study and signed by the researcher. After one reminder, a total of 146 usable questionnaires were returned, representing a response rate of $41.35 \%$. The survey for 
this study relies on data collected from managers of IJVs, CBM\&As and FWOS in Norway. The study considers the ex post assessment of managers' perception of the relative importance of the motivation behind the choice of entry mode at the time of entry into Norway. As the questions were of strategic in nature, it was determined that respondents should be upper level managers of IJVs, CBM\&As and FWOGSs in Norway. An examination of the job titles of the respondents revealed that $61.64 \%$ were chief executives, $16.43 \%$ finance directors, $11.66 \%$ marketing directors and $10.27 \%$ other senior managers. Clearly, the responses were from top officials of the firms. According to Miller et al. (1997), this high level involvement is important and may significantly reduce the risk of informant fallibility and wrong post hoc attributions.

The non response bias was tested using Armstrong and Overton's procedure (1977). A t-test was implemented to compare responses before and after the deadline along the key characteristics of the sample. There were no significant differences between the two groups, suggesting that non-response bias was not a serious problem in this study.

\subsection{Characteristics of the Sample}

Table 1 shows that the response rate for the usable replies of 146 representing $41.35 \%$. A response rate of $41.35 \%$ compares favourably with comparable studies, such as the one by Nakos and Brouthers (2002), which investigated entry-mode choice in Central and Eastern Europe and received a response rate of $28.2 \%$. A careful examination of the sample characteristics shows that, with regard to entry modes, the highest response rate was from CBM\&As (36.30\%), followed by WOGS (34.94\%), 
and the lowest was from IJVs (28.76\%). The sector responses reveals that $73.98 \%$ of respondents were from the manufacturing sector and $26.02 \%$ from the services sector. In terms of firm size, $65.76 \%$ of the respondents were small sized firms, while $35.24 \%$ were medium firms. In terms of ownership type, $54.11 \%$ were privately owned, and $45.98 \%$ were publicly owned firms. The sample characteristics reveal that $86.98 \%$ of the firms in the sample were firms with previous international experience, and $13.02 \%$ were firms with no previous international experience. With regard to the data collection method, the highest response rate was received from personal delivery and collection of the questionnaire. A total of 55 questionnaires were delivered personally, and 50 were received, which represents a $90 \%$ response rate. Out of the total 168 questionnaires sent via post, 52 were received, representing a response rate of $30.98 \%$. For the online survey, 130 were sent and 44 received, a response rate, of $33.84 \%$.

\section{(Insert Table 1 Here)}

\section{Statistical Analysis}

Our analysis began with one way t-tests to determine the relative importance of each performance measure to the respondent firms in assessing performance. To examine the hypothesised relationships, correlation coefficients were computed, and hypotheses 1, 2, 3, 4 and 5 were tested using multiple regression analysis. A variance of inflation 
factor test of the independent and dependent variables of the study was conducted to identify any collinearity problems. The VIF scores are well within the cut-off point of 10, as recommended by Neter, Wasserman, and Kutner (1985). Multicollinearity appears not to be a problem in this study.

\subsection{Dependent Variable}

The performance of the three entry modes (MODE) was measured using a composite variable, that is, the summation of the following terms: multiplicative interaction of the relative importance attached to each of the following measures and the levels of satisfaction with regard to performance measures; such as sales growth, profitability, returns on total assets share price, market share, transfer of technology, employee satisfaction, labour productivity, quality control, improved channels of distribution, improved R\&D capacity, returns on sales and product reputation. Following Pangarkar (2008) and Boateng and Glaister (2002) we operationalised performance as: the sum of performance measures $=$ the mean score of the relative importance of each measure $\mathrm{x}$ the level of satisfaction with regard to each performance measure.

Table 2 shows how the independent variables were measured

(Insert Table 2 Here Please)

\section{Results and Discussion}




\subsection{Measures of Performance}

Table 3 shows the relative importance of the performance measures to the respondent firms. It is apparent from the table that all the performance measures were statistically significant at $1 \%$, with respect to the respondent firms in the sample. Profitability, sales growth, returns on total assets, share price and market share are among the most important performance measures for all three entry modes.

(Insert Table 3 here please)

\subsection{Factors Influencing Performance}

Table 4 shows a summary of the means, standard deviations and correlation matrix for the independent variables, the dependent variable and the three entry modes (MODE). Bivariate relationships shown in Table 4 indicate the size of the firm $(\mathrm{p}<0.01)$ and sector of operation $(\mathrm{p}<0.01)$. The overall performance is negatively correlated with the ownership type of the company and positively correlated with previous international experience, but these results are not statistically significant.

\subsection{Main Regression Results}

Table 5 presents the results of multiple regressions that were conducted to predict the overall performance of IJVs, CBM\&As and FWOGS in Norway. The table shows that 
the $F$-value is significant $(\mathrm{p}<0.01)$ and that the adjusted $\mathrm{R}$ ranges from $31.2 \%$ to $56.2 \%$ of the variation in the performance of the three entry modes.

The size of the firm has a positive and significant relationship in two out of the three modes of entry. This provides some support for $\mathrm{H} 1$. The positive sign for CBM\&As and FWOGS indicates that firm size has a positive and significant influence on SME performance. This finding is not surprising and appears to be consistent with the conclusion drawn by Pangarkar (2008) and Bourlakis, et. al (2014), who stated that SMEs are more efficient than large firms. This argument is also supported by Ingham et al. (1992), who argued that small acquisitions are easier to integrate compared to large acquisitions. Moreover, the transaction cost theory supports the notion that the additional hierarchical layers in large firms can complicate the internal communication, leading to loss of control by senior managers (Williamson, 1970). This, in turn, results in greater distance between the subordinates and their managers and therefore less information about the opportunist behaviour of senior management. In addition, Williamson (1975) argues that stockholders control over management becomes more difficult when a firm grows in size and complexity, leading to poor performance.

However, the IJVs have a negative coefficient, suggesting that small size exerts negative influence on SMEs performance. This finding is surprising in that it is contrary to our prediction that small IJVs are more likely to perform poorly due, perhaps, to potential conflicts between partners. However, this finding differs from the literature on "Born Global" firms, which suggests that the use of IJVs might help 
SMEs to overcome both financial and managerial resources constraints and improve performance.

Regarding the sectors of operation and SMEs performance, the results show positive and statistically significant impact across the three models (model 1 at $p<0.1$, model 2 at $\mathrm{p}<0.01$ and model 3 at $\mathrm{p}<0.01$ ) suggesting that the sector of operation exerts significant influence on the performance of each entry mode. As expected, sectors of operation have a positive correlation with the overall performance of CBM\&A and FWOGS. However, in term of IJV, the coefficient was negative and significant. This suggests that sectors such as natural resources, where the Norwegian government is likely to be a partner to the IJV because of their strategic importance to the state, tend to have poor performance.

Ownership type of the IJVs was negative and statistically significant for the performance $(\mathrm{p}<0.05)$. This is not surprising; as suggested by Kvinge and Narula (2001) and Raveed and Renforth (1983), IJVs with government as a partner may become entangled in internal disagreements, politics and bureaucracy, slowing down the activities and decision-making processes of the enterprise and consequently exerting negative influence on performance. However, this may not be the case for sole ventures (Newburry and Zeira, 1997). The Norwegian government as partners to IJVs have different goals and priorities compared to private enterprises (NHO, 2003), which negatively influence performance. The finding is consistent with the findings of the studies by Goldeng et al. (2008). Contrary to our expectation, H4 is not supported. 
The results are not statistically significant in any of the models. This suggests that previous international experience does not have any implications for the overall performance of any of the entry modes. This result is consistent with that of Lubatkin (1982) who conducted a study on the acquisition experience of firms listed on the Federal Trade Commission's Large Merger Series from 1948 to 1979 and failed to find a significant association between acquisition experience and performance. The coefficient for trust between partners is positive and statistically significant at $(\mathrm{p}<0.01)$, and the convergence of strategic goals is significant at $(\mathrm{p}<0.05)$. Hypotheses $5 \mathrm{a}$ and $5 \mathrm{~b}$ are therefore supported. Thus, trust between the joint venture partners and the convergence of their strategic goals do affect performance of the joint ventures, which is consistent with the majority of the JV literature (see: Boateng and Glaister, 2002; Boersma, et al., 2003; Buckley and Casson, 1988 and Larimo, Nguyen, and Ali, 2016). The trust and convergence of strategic goals between partners to the IJV help reduce uncertainty about the other party's behaviour, improve personal attachment and, consequently, improve performance. On the other hand, disagreements about partners' goals generate an opportunistic environment and create conflicts (Luo and Park, 2004).

(Insert Table 5 Here)

\section{Robust Checks}

Table 6 summarises the regression results using alternative performance. Following Sim and Ali (1998), performance was measured using a composite index (an 
arithmetic average score) without weight. We find that the alternative measure of performance has the same qualitative results as in our main results (Table 5). The exception is the sector of operation, which does exhibit a lower impact for CBM\&A. In fact, the magnitude of the former effect is much greater than the latter one. Additionally, we note a negative and significant impact of ownership type in respect to Table 6 compared to our main results, which indicate that negative insignificant impact on performance. We also note that our main results in Table 5 have better explanatory power, ranging from an adjusted $\mathrm{R}$ of $31.2 \%$ to 56.6 compared to $16 \%$ to $54.9 \%$. In summary, our main results are robust to the alternative measure.

(Insert Table 6 here)

\section{Implications and Conclusion}

In this study, we examined the performance implications of equity entry mode choice of SMEs entering Norway. Using a cross-sectional questionnaire survey, a sample of 146 SMEs were analysed. Our results indicate that the multi-item measures of performance used in this study were statistically significant measures for all the firms in the sample. However, the relative importance of each measure differs among the firms and, as a result, we considered the multiplicative interaction of the relative importance attached to each of the measures and the level of satisfaction to derive the performance measure in this study. The employment of a broader perceptual measure of performance, which considers financial and non-financial measures, is significant 
in that it inspires confidence in our results. A robust check using an alternative performance measure yields similar qualitative results. In this way, this study contributes to resolving the problems associated with measuring performance. We suggest that our approach to measuring performance may advance existing management research.

Turning to the cross-sectional regression results, we found that the size of the firm and sector of operation have a significant relationship with CBM\&As and FWOGS and all the three entry modes, respectively. The finding that size influences the performance of SMEs suggests that small firms are more flexible than large multinational firms due to their size and a lesser degree of organisational inertia, consistent with the view of Criculolo and Narula (2007); Hannan et al., (2002) and Benito-Osorio et. al. (2016). Sectors are positively and significantly related to the performance of CBM\&As and FWOGS but are negatively associated with IJVs, which tend to have government as partners. The results indicate that ownership type, trust and convergence of strategic goals are significantly related to the overall performance of IJVs, while previous international experience did not have any significant relationship with the entry modes. Our study has several implications for SME managers. First, our results imply that prior international experience does not help to overcome the transaction costs and enormous location-specific advantages in Norway and hence the negative influence on performance. However, firm characteristics, namely, size and sector of operation, tend to have significant influence on SME performance. Second, IJVs with 
government as a partner tend to exhibit poor performance. However, trust and congruity of strategic goals are important factor for IJV performance.

As is the case of most empirical studies, this study has a limitation. Our analysis is based on cross-sectional rather than panel data. Given the interesting findings with regard to the influence of firm characteristics and negative but not significant influence of prior international experience, a useful extension for future research would be to examine the evolution of foreign entry modes and the performance of SMEs using a longitudinal design. This will allow an explicit modelling of the impact of international experience and other host country institutional variables not considered in this study.

\section{References:}

Ainuddin, A. R., Beamish, P., W, Hulland, J. S., \& Rouse, M. J. (2007). Resource attributes and firm performance in international joint ventures. Journal of World Business, 42, 47-60.

Annavarjula, M., \& Beldona, S. (2000). Multinationality-performance relationship: A review and reconceptualization. International Journal of Organizational Analysis, 8: $48-67$.

Armstrong, S. J., \& Overton, T. S. (1977). Estimating Non-response Bias in Mail Surveys. Journal of Management Research, 14, 396-402.

Anderson, E. \& Gatignon, H. (1986). Modes of Foreign Entry: A Transaction Cost Analysis and Propositions. Journal of International Business Studies, 17(3), 1-26.

Anderson, E. (1990). Two firms, One Frontier: On Assessing Joint Venture Performance, Sloan Management Review, 31(2), 19-30.

Andersson, U., Forsgren, M., \& Pedersen, T. (2001). Subsidiary performance in multinational corporations: the importance of technology embeddedness, International Business Review, 10, 3-23. 
Barringer, B.R. \& Greening, D.W. (1998). Small business growth through geographic expansion: a comparative case study. Journal of Business Venturing 13: 467-492.

Beamish, P., \& Delios, A. (1997 ). Improving joint venture performance through congruent measures of success. In P. Beamish \& J. P. Killing (Eds.), Cooperative strategies, European perspectives (pp. 103-127). San Francisco, CA: The Lexington Press.

Beamish, P. W., \& Lupton, N. C. (2009). Managing Joint Ventures. Academy of Management Perspectives, 23(2), 75-94.

Becker, Thomas H., and James L. Porter (1983), "Small Business Plus Export Trading Companies: New Formula for Export Success?" Journal of Small Business Management (October), 8-16.

Benito, G., Grøgaard, B., \& Narula, R. (2003). Environmental influences on MNE subsidiary roles: economic integration and the Nordic countries. Journal of International Business Studies, 34, 5, 443-456

Benito-Osorio, D. Colino, A., Guerras-Martín, L_A., José Ángel Zúñiga-Vicente, J-A. (2016). The international diversification-performance link in Spain: Does firm size really matter. International Business Review. Vol 25, (2), pp0. 548-558

Berger, A. L. (1995). The profit stucture relationship in banking: Test of market power and efficient structure hypotheses. Journal of Money Credit and Banking, 27(2) 404-432.

Bhattacharyya, S., \& Saxena, A. (2009). Does the Firm Size Matter? An Empirical Enquiry into the Performance of Indian Manufacturing Firms. Indian Institute of Technology and Institute of Management Technology

Boateng, A., \& Glaister, K. W. (2002). Performance of international joint ventures: evidence for West Africa. International Business Review, 11(5), 523.

Boateng, A., Hua, X., Nisar, S. and Wu, J. (2015) Examining the determinants of inward FDI: Evidence from Norway. Economic Modeling. Vol. 47, (C) pp.118-127

Boersma, M. F., Buckley, P. J., \& Ghauri, P. N. (2003). Trust in international joint venture relationships. Journal of Business Research, 56(12), 1031-1042.

Bourlakis, M., Maglaras, G., Aktas, E., Gallear, D. and Fotopoulos, C. (2014). Firm size and sustainable performance in food supply chains: Insights from Greek SMEs. 
International Journal of Production Economics. Vol 152, (June), 112-130.

Boyd, J. H., \& Graham, S. L. (1991). Investigating the banking consolidation trend, Federal Bank of Minnesota Quarterly Review, 3-15.

Brouthers, K. D. (2002). Institutional, Cultural and Transaction Cost Influences on Entry Mode Choice and Performance. Journal of International Business Studies, 33(2), 203-221.

Brouthers, K. D., \& Nakos, G. (2004). SME Entry Mode Choice and Performance: A Transaction Cost Perspective. Entrepreneurship Theory and Practice, 28(3), 229 -247.

Buckley, P. J., \& Casson, M. (1976). The Future of the Multinational Enterprise, London: Macmillan.

Buckley, P. J., \& Casson, M. (1988). A Theory of co-operation in international business. In F. J. Contractor \& P. Lorange (Eds.), Co-operative strategies in International Business.Lexington, MA: Lexington Books.

Carlsson, J., Nordegren, A., \& Sjoholm, F. (2005). International Experience and the Performance of Scandinavian Firms in China. International Business Review, 14, 21-40.

Carrier, C. (1994). Intrapreneurship in Large Firms and SMEs: A comparative study, International Small Business Journal, 12 (3): 54-61

Caves, R. E., \& Mehra, S. K. (1986). Entry of foreign multinationals into US manufacturing industries. In M. E. Porter (Ed.), Competition in global industries, Boston: Harvard Business School Press.

Chen, C., \& Findlay, C. (2003). A Review of cross- border mergers and acquisitions in APEC, Asian-Pacific Economic Literature, 17(2), 14-38.

Child, J., \& Yan, Y. (2003). Predicting the performance of international jointventures: An investigation in China. Journal of Management Studies, 40, 283-320.

Choo, S. \& Mazzarol, T. (2001). An Impact on Performance of Foreign Market Entry Choices by Small and Medium-Sized Enterprises. Journal of Enterprising Culture, 9(3), 291-312.

Collins, J. M. (1990). A market performance comparison of US firms active in domestic, developed, developing countries. Journal of International BusinessStudies, 
Coviello, N.E. \& McAuley, A. (1999). Internationalization and the Smaller Firm: A Review of Contemporary Empirical Research. Management International Review, 39(3), 223-256.

Delios, A., \& Beamish, P. W. (2001). Survival and profitability: The roles of experience and intangible assets in foreign subsidiary performance. Academy of Management Journal, 44(October), 1028-1038.

Deeds D.L and Hill CWL. 1998. An examination of opportunistic action within research alliances: evidence from the biotechnology industry. Journal of Business Venturing 11(1): 41-56.

DFAT (1995). Winning Enterprises: How Australia's Small and Meduim Enterprise compete in Global Markets: Department of Foreign Affairs and Trade, AGPS, Canberra

Dikova, D. (2009). Performance of foreign subsidiaries: Does psychic distance matter? International Business Review, 18, 38-49.

Ellingsen, M. (2008). Norge i EØS-Mektig eller avmektig? En analyse av norges påvirkningsmuligheter og tilpasning i forhold EU's rettsakter. University of Troms $\varnothing$, Troms $\varnothing$.

Elnihewi, I., Fadzil, F.H. and Mohamed, R (2014) The Effect of Institutional Factors on the Organizational Performance through Performance Measures of Commercial Banks in Libya. Procedia -Social and Behavioral Sciences. Vol. 164: 635-340

Erramilli, M.K. \& D’Souza, D.E. (1993). Venturing into Foreign Markets: The Case of Small Service Firms. Entrepreneurship Theory \& Practice, 12(3), 29-41

Erramilli, M.K. \& Rao, C.P. (1993). Service Firms' International Entry-Mode Choice: A Modified Transaction-Cost Analysis Approach. Journal of Marketing, 57(3), 19-38.

Evans, J., Mavondo, F. T., \& Bridson, K. (2008). Psychic distance: Antecedents, retail strategy implications and performance outcomes. Journal of Marketing, 15(2), 32-63.

Fey, C. F., \& Beamish, P. W. (2000). Joint venture conflict: the case of Russian 
international joint ventures. International Business Review, 9, 139-162.

Geringer, M.J. (1990). Strategic determinants of partner selection criteria in international joint ventures, Journal of International Business Studies, First Quarter, 41-61.

Geringer, J. M., \& Hebert, L. (1991). Measuring Performance of International Joint Ventures, Journal of International Business Studies, 22(2), 249-263.

Geringer, J. M., Beamish, P. W., \& daCosta Richard, C. (1989). Diversification strategy and internationalization: Implication for MNE performance. Strategic Management Journal, 10: 109-119.

Goldeng, E., Grünfeld, L. E., \& Benito, G. R. (2008). The Performance Differential between Private and State Owned Enterprises: The Roles of Ownership, Management and Market Structure. Journal of Management Studies, 45(7), 1244-1273.

Government Norway. (2007). The oil market and Norway. Oslo: Ministry of Petroleum and Energy.

Hamel G. 1991. Competition for competence and interpartner learning within international strategic alliances. Strategic Management Journal Summer, Special Issue 12: 83?03.

Hannan, M. T., Laszlo, P. and Carroll, G. R. (2002). Structural Inertia and Organizational Change Revisited: The Evolution of Organizational Inertia. Research Paper Series, Stanford University, Graduate School of Business, Stanford, CA.

Harzing, A. W. (2002). Acquisitions vs. Greenfield Investments: International Strategy and Management of Entry Modes. Strategic Management Journal, 23(3), 211-227.

Hayward, M. (2002). When Do Firms Learn From Their Acquisition Experience? Evidence From 1990-1995. Strategic Management Journal, 23(1), 21-40.

Hennart J-F. 1982. A Theory of Multinational Enterprise. University of Michigan Press: Ann Arbor, MI.

Hennart, J.F. (1989). Can the 'New Forms of Investment' Substitute for the 'Old Forms?': A Transaction Costs Perspective. Journal of International Business Studies, 20(Summer), 211-234.

Hennart, J.F. (1991). The Transaction Costs Theory of Joint Ventures: An Empirical 
Study of Japanese Subsidiaries in the United States. Management Science, 37(4), 483-497.

Hill, C.W. and Kim, W.C. (1988). Searching for a dynamic theory of multinational enterprise: a transaction cost model, Strategic Management Journal, 9, (Summer, Special Issue): 93-104.

Hoskisson, R. M., \& Hitt, M. A. (1990). Antecedents and performance outcomes of diversification: A review and critique of theoretical perspectives. Journal of Management, 40(4): 767-798.

Hymer SH. 1976. A Study of Direct Foreign Investment, MIT Press: Cambridge, MA.

Ingham, H., Kran, I., \& Lovestam, A. (1992). Mergers and Profitability: A Managerial Success Story. Journal of Management Studies, 29(2), 195-209.

Ismail, A. I., Rose, R. C., Abdullah, H., \& Uli, J. (2010). The relationship between organisational competitive advantage and performance moderated by the age and size of firms. Asian Academy of Management Journal, 15(2), 157-173.

Johanson, J., \& Vahlne, J.-E. (1977). The Internationalization Process of the Firm - A Model of Knowledge Development and Increasing Foreign Market Commitments, Journal of International Business Studies, 8, 23-32.

Johanson, J., \& Vahlne, J.-E. (1990). The Mechanism of Internationalzation, International Marketing Review, 7(4), 11-24.

Kaufmann, F. (1995). Internationalisation via co-operation - Strategies of SME, International Small Business Journal, 13 (2) 27-33

Ketokivi, M. A., \& Schroeder, R. G. (2004). Strategic, structural contingency and institutional explanations in the adoption of innovative manufacturing practices. Journal of Operations Management, 22(1), 63-89

Klein, S., Frazier, G.L., \& Roth, V.J. (1990). A Transaction Cost Analysis Model of Channel Integration in International Markets. Journal of Marketing Research, 27(May), 196 -08.

Kogut B. 1989. The stability of joint ventures: reciprocity and competitive rivalry. Journal of Industrial Economics 38: 183-198.

Kogut B. 1985. Designing global strategies: profiting from operational flexibility. 
Sloan Management Review 26: 27-38.

Kumar, M. S. (1984). Comparative analysis of UK domestic and international firms. Journal of Economic Studies, 11(3): 26-42.

Kvinge, T., \& Narula, R. (2001). FDI in Norway's manufacturing sector Oslo: Norwegian Research Council, Report

Larimo, J., Nguyen, H.L., Ali, T. (2016). Performance measurement choices in international joint ventures: What factors drive them? Journal of Business Research, Vol 69, (2), pp. 877-887

Laufs, K. and Schwens, C. (2014). Foreign market entry mode choice of small and medium-sized enterprises: A systematic review and future research agenda. International Business Review. Vol. 23. pp. 1109- 1126.

Lewin, A. Y., \& Minton, J. W. (1986). Determining Organizational Effectiveness: Another look, and an Agenda for Research. Management Science, 32(5), 514-538.

Levitt, T. (1983). “The Globalization of Markets," Harvard Business Review, (May/June), 92-102.

Li, J., \& Guisinger, S. (1991). Comparative Business Failures of Foreign-Controlled Firms in the United States. Journal of International Business Studies (2 nd Quarter), 209-224.

Liu, C.-L. E., Ghauri, P., \& Sinkovics, R. R. (2010). Understanding the impact of relational capital and organizational learning on alliance outcomes. Journal of World Business, 45, 237-249.

Lu, J. W., \& Beamish, P. W. (2001). The internationalization and performance of SMEs. Strategic Management Journal, 22(6/7): 565-584

Lubatkin, M. H. (1982). A market model analysis of diversification strategies and administrative experience on the performance of merging firms University of Tennessee.Thesis

Luo, Y. \& Peng, M.W. (1999). Learning to Compete in a Transitional Economy: Experience, Environment and Performance. Journal of International Business Studies, 39(2), 269-295.

Luo, Y., \& Park, S. H. (2004). Multiparty cooperation and performance in 
international equity joint ventures. Journal of International Business Studies, 35, 142-160.

Madhok, A. (1995). Revisiting Multinational Firm's Tolerance for. Joint Ventures: A Trust-based Approach. Journal of International Business Studies, 26(1), 117-137.

Maekelburger, B., Schwens, C., and Kabst, R. (2012). Asset specificity and foreign market entry mode choice of small and medium-sized enterprises: The moderating influence of knowledge safeguards and institutional safeguards. Journal of International Business Studies, 43(5), 458-476.

McCloughan, P., \& Stone, I. (1998). Life duration of foreign multinational subsidiaries: Evidence from UK northern manufacturing industry 1970-93. International Journal of Industrial Organisation, 16, 719-747.

Miller, G., Tybar, J.M., and Jordan, B.D. (1997). Ovulatory cycle effects on tips earnings by lap dancers: economic evidence for human estrus, Evolution and Human Behaviour, vol. 28, issue 6, pp.375-381.

Milliken, F.J. (1987). Three types of uncertainty about the environment: state, effect and response uncertainty, Academy of Management Review, 12, pp.133-143

Morck, R., \& Yeung, B. (1991). Why investors value multinationality. Journal of Business, 64(2): 165-187.

Nakos, G. \& Brouthers, K.D. (2002). Entry Mode Choice of SMEs in Central and Eastern Europe. Entrepreneurship Theory \& Practice, 27(1), 47-64.

Nachum, L. (2001). The impact of home countries on the competitiveness of advertising TNCs, Management International Review, 41, pp. 77-98.

Neter, J., Wasserman, W., \& Kutner, M. H. (1985). Applied linear statistical models: Regression, analysis of variance, and experimental design. Homewood, IL: Irwin.

Newburry, W., \& Zeira, Y. (1997). Generic Differences Between Equity International Joint Ventures (EIJVs), International Acquisitions (IAs) and International Greenfield Investments (IGls): Implications for Parent Companies. Journal of World Business 32(2), 87-102.

NHO. (2003). Norsk utviklingspolitikk- hvorfor skal norsk naringsliv engasjere seg? Oslo, Norway: Report by Norges Handels Organisasjon 
Nisar, S., Boatneg, A., Wu, J. and Leung, M (2012). Understanding the motives for SMEs entry choice of international entry mode. Marketing Intelligence and Planning. Vol. 30 Iss: 7, pp.717 - 739

Nooteboom, B. (1996). Trust, opportunism and governance: a process and control model Organisation Studies, 17(6), 985-1010.

Nooteboom, B., Berger, H., \& Noorderhaven, N. G. (1997). Effects of trust and governance on relational risk. Academy of Management Journal, 40(2), 308-338.

OECD. (2003). Regulatory Reform in Norway - Marketisation of government services - state owned enterprises. Paris, France.

OECD. (2010). Economic Survey of Norway 2010. Paris: Organisation for Economic Cooperation and Development.

Okręglicka, M. Gorzeń-Mitka, I. and Ogrean, C (2015). Management Challenges in the Context of a Complex View - SMEs Perspective. Procedia Economics and Finance, Vol 34, pp 445-452

Oviatt, B. \& McDougall, P. (1997). Global Start-ups: Entrepreneurs on a worldwide stage, Academy of Managent Executuve, 9, 2, 30-43

Oviatt, B. \& McDougall, P. (1997). Challenges for Internationalization Process Theory: The Case of International New Ventures. Management International Review, 37(2), 85-99.

Pan, Y., \& Chi, P. S. K. (1999). Financial performance and survival of multinational corporations in China. Strategic Management Journal, 20, 359-374.

Pangarkar, N. (2008). Internationalization and performance of small and medium sized enterprises. Journal of World Business, 43, 475-485.

Papadopculos, N. (1987). Approaches to International Market Selection for Small and Medium -Sized Enterprises, In P.Rosson and S. Reid (Eds), Managing Export Entry and Expansion, New York, Praeger.

Parkhe, A. (1993). Trust in international joint ventures. Paper presented at the Academy of International Business Meeting 1993, Hawaii.

Raveed, S. R., \& Renforth, W. (1983). State enterprise-multinational corporation joint ventures: How well do they meet both partners' needs? Management International 
Review,1(1), 47-57.

Ring, P. S., \& Van De Ven, A. H. (1994). Developmental processes of co-operative interorganizational relationships. Academy of Management Review, 19, 90-118.

Shaked, I. (1986). Are multinational corporations safer? Journal of International Business Studies, 17(1): 75-80.

Schwens, C., Eiche, J. and Kabst, R. (2011). The moderating impact of informal Institutional distance and formal institutional risk on SMEs Mode Choice, Journal of Management Studies, 48, 2, pp.330-351

Shaver, J. M., Mitchell, W., \& Yeung, B. (1997). The effect of own-firm and other-firm experience on foreign direct investment survival in the United States, 1987-92 Strategic Management Journal, 18, 811-824.

Shuman, J. \& Seeger, J. (1986). The Theory and Practice of Strategic Management in Smaller Rapid Growth Firms. American Journal of Small Business, 11(1), 7-19.

SSB (2011). Statistical Yearbook of Norway 2009. Oslo / Kongsvinger: Statistical Central Bureau, Norway.

SSB (2014). Statistical Yearbook of Norway 2012. Oslo / Kongsvinger: Statistical Central Bureau, Norway.

Stoian, M.-C., Rialp, J., and Dimitratos, P. (2016) SME networks and international performance: unveiling the significance of foreign market entry mode. Journal of Small Business Management, Accepted for publication

Tsai M-T, Tung W-H , (2014) "Corporate governance, resources, FDI commitment and firm performance: Empirical analyses of Taiwanese high-tech firms", Chinese Management Studies, Vol. 8 (3), pp.313 - 332

UNCTAD. (2000). World Report 2000: FDI and the Challenge of Development. New York and Geneva: United Nations Conference on Trade and Development.

Venkatraman, N., \& Ramanujam, V. (1986). Measurement of Business Performance in Strategy Research: A Comparison of Approaches. Academy of Management Review, 11(4), 801-814.

Weaver KM, Dickson PH. 1998. Outcome quality of small- to medium-sized enterprise-based alliances: the role of perceived partner behaviors. Journal of 
Business Venturing 13(6): 505-522.

Williamson, O.E. (1985). The Economic Institutions of Capitalism. New York: The Free Press

Williamson, O. E. (1970). Corporate control and business behavior. Englewood Cliffs, NJ: Prentice-Hall.

Williamson, O. E. (1975). Markets and Hierarchies. Englewood Cliffs, NJ:

Prentice-Hall

Williamson, O.E. \& Ouchi, W.G. (1981). The Markets and Hierarchies and Visible Hand Perspectives. In Van de Ven, A. \& Joyce, W. (eds.), Perspectives on Organization Design and Behavior, New York: Wiley.

Woodcock, P., Beamish, P. W., \& Makino, S. (1994). Ownership-Based Entry Mode Strategies and International Performance. Journal of International Business Studies, 25(2), 253-273.

Zacharakis, A. L. (1997) 'Entrepreneurial Entry into Foreign Markets: A Transaction Cost Perspective', Entrepreneurship Theory and Practice 21(3): 23-39.

Zahra SA, Ireland RD, Hitt MA. 2000. International expansion by new venture firms: international diversity, mode of market entry, technological learning and performance. Academy of Management Journal, 43(5): 925-950. 
